\title{
PANDEMIC LESSONS: THE NEED FOR A NEW POLITICAL THINKING
}

\author{
Vladimir F. Pryakhin ${ }^{13}$ \\ Russian State University for the Humanities, Moscow
}

\begin{abstract}
With the beginning of the new Cold War, the new political thinking so popular during perestroika initiated in the USSR, disappeared in the political vocabulary. This happened for a number of reasons, such as: Gorbachev's new political thinking has practically fulfilled its historical destination to unite the international community for preventing the threat of a nuclear war; after the elimination in the 90-s of the direct danger of a world war interstate rivalry, political competition for spheres of influence, markets and sources of raw- and energy materials resumed; integrative ideology was replaced by nationalist, separatist and consumerist ideological clichés; and the idea of a civilizational split began to be intensively implanted.

The COVID-19 pandemic revealed the illusion that with the end of the Cold War all global threats disappeared. It became obvious that humanity is increasingly becoming a hostage of scientific and technological progress. The need for joint countering new challenges became more evident than ever. The scientific community returned to the question of what should be the new thinking to integrate the disintegrated international community. Our vision of such an integrative ideology includes basic components as follows: urgent need for global governance; identification of the optimal forms and fora of increasing the level of global governance; increasing the role of international organizations (in particular, WHO); developing an integrated universally acceptable set of moral principles and values; search for ways to improve inter-civilizational dialogue, overcoming social schism, working out the idea of an interfaith universal church.
\end{abstract}

Keywords: pandemic, global problems, global governance, new political thinking.

\section{Pandemic and new political thinking}

With the beginning of the new Cold War, the concept of new political thinking, which was so popular during the perestroika initiated in the USSR by Mikhail Gorbachev, was excluded from the political vocabulary of world public opinion. Meanwhile, the vicissitudes of the world community's confrontation with the global infection clearly indicated the need to overcome the political fragmentation of states and nations, to form a worldview that unites the broad masses of people in different countries.

This happened for the following reasons:

M. Gorbachev's new political thinking has practically fulfilled its historical purpose, uniting for some time the international community in the face of the real threat of a third world war with the use of weapons of mass destruction; Over the three years from 1988 to

${ }^{13}$ Contact address: pryakhin2010@mail.ru 
1990, the hands on the Doomsday clock, established by atomic scientists to indicate the time interval separating humanity from a nuclear catastrophe, were set aside from fatal midnight by as much as ten minutes to $23-43$. This was and remains the furthest from midnight position of the hands of the Doomsday Clock in their entire history. Even now, when the new Cold War has led to the fact that the hands of this watch approached the fatal line by fifteen minutes and are at the closest distance from midnight in the entire history of this watch, the likelihood of global nuclear catastrophes is still estimated by experts and politicians as hypothetical threat. This also reflects the positive legacy of the new political thinking of the 1980 s and 1990s.

In subsequent years, however, interstate rivalry resumed, the political struggle for spheres of influence, markets and sources of raw materials. The practice of the so-called 'double standards' in assessing the degree of realization of human rights and democratic freedoms has spread, integrative new political thinking has replaced nationalistic, separatist worldview clichés; the ideology of a civilizational split began to be intensively implanted.

\section{Pandemic and the need for ideology}

The COVID-19 pandemic once again really showed the international community the illusory notion that with the end of the Cold War all global threats have been eliminated. It became obvious that mankind is increasingly becoming a hostage of scientific and technological progress. The need for joint confrontation of the international community to new challenges and threats was indicated. This prompted the scientific community to return to the topic of new political thinking.

However, there is no clear idea of what should be the basis of the ideology that unites humanity. This is due to the fact that there is no uniform interpretation of the very terms of ideology (worldview). Moreover, the opinion about the harmfulness of ideology for the international order has developed and is still actively promoted. De-ideologization of politics is elevated to the rank of universal human virtue. One of the articles devoted to the foreign policy of the XXI century, published in the authoritative journal "Russia in Global Affairs", is called "After the death of ideology" (Yakovenko, 2014). Therefore, before expounding our understanding of the ideology necessary for the transition to a qualitatively new round in the history of mankind, it is necessary to clarify the very definition of ideology as such.

The term ideology was introduced into scientific use at the end of the 18th century by the prominent French philosopher, politician and economist A.-L.-K. Antoine-Louis-Claude Destut de Tracy Antoine-Louis-Claude Destut de Tracy (1754 - 1836) to indicate the general laws of the origin of ideas from the content of sensory experience. The generalization of these patterns brought into the system was supposed to become a kind of guide / instruction in science and life. In it A.-L.-K. Destut de Tracy saw the beginning of what is called ideology in the proper sense of the word; and all the consequences that are derived from them are subjects of grammar, logic, pedagogy, private and public morality (that is, the art of living in society), education, legislation, which is nothing more than the education of adults. We will not be able, therefore, in all these sciences to fall into error, unless we lose sight of the fundamental observations on which they are based (Destütt de Tracy, 1817: 215). This instruction was and remains necessary in order to foresee the future, form goal-setting and make the right decisions to forestall possible dangers and ensure national interests. 
Subsequently, religion, philosophy and aesthetics were included in this system (Soviet encyclopedic dictionary, 1979:48).

The French thinker thus wanted to provide a scientific basis for the progressive reforms of Napoleon, who laid the foundations of bourgeois France, and indeed of all continental Europe. Napoleon, however, perceived the ideas of Destut de Tracy as too abstract and distracting from the immediate tasks of concrete politics. With the light hand of the great politician, the second understanding as a false, illusory consciousness divorced from reality was also entrenched for a long time to ideology (Great Encyclopedia of Cyril and Methodius, 1998). The disagreement between Destut de Tracy and Napoleon is a prime example of the contradiction between scientist and politician. Collisions of this kind accompany the entire history of the world. Suffice it to recall the famous dialogue between Diogenes and Alexander the Great. To the question of the great commander what he can do for him, the great philosopher-bum, answered from the barrel: "Move away, you are covering the Sun for me."

It seems that in our time, the denial of ideology as a fundamental worldview concept, independent of the political environment, is a kind of continuation of these historical debates between philosophers and politicians. But in the era of globalization, this discussion acquires a qualitatively new topical significance, since the international community, humanity and each individual taken in order to counter the global threats to the existence of life on Earth, absolutely need a clear and unambiguous understanding of the meaning of life and human history. Otherwise, the emphasis of vital activity is automatically transferred to consumption and overconsumption as the main and only goals of the existence of mortal man on the finite Earth. Nobel laureate Albert Gore warned about the danger of such a re-emphasis of the values of being, expressing the opinion that the ideology of over-consumption is more dangerous for humanity than the ideology of Hitler's totalitarianism. The correctness of this judgment is partly confirmed by the fact that the thinker of the opposite political paradigm, agreed with him Fidel Castro," who asserted: "The ideology of consumption imposed by the United States on the world threatens all of humanity" (The Ideology of Overconsumption, 2016).

The global crisis due to the COVID-19 coronavirus pandemic has confirmed the correctness of the judgments of A. Gore and F. Castro. The general trend is that the virus has most affected the countries in which the ideology of consumerism (consumerism) is most widespread. At the same time, in countries with stronger morale and tighter government control, the damage from the coronavirus was lower, and the dangers of its spread were eliminated faster.

\section{Religion and ideology}

The global offensive of the consumerist ideology continues. The thirst for consumption is spreading more and more. And this is natural, since the level of consumption in the overwhelming majority of countries of the world is still extremely low. And there is nothing wrong with trying to raise it. One can only welcome the fact, for example, that the lowest level of poverty is eliminated in the largest state of our time in the People's Republic of China. But at the same time, one cannot ignore the fact that consumption and the ideology of consumerism are definitions with different material content. One of the main problems of our time is that the growth of consumption is accompanied by the spread of consumerist 
ideology. The cult of consumption becomes the only vital stimulus of human life and activity in the era of globalization.

In the pre-globalization era, the origins of morality, spirituality and a clear understanding of the meaning of life were rooted in the sacred religious concepts of immortality and resurrection. The religion itself originated when the Sumerian King Gilgamesh was afraid of death and cried out at the grave of his faithful friend Eabani (Enkidu):

And now I am afraid of death, and I run into a deserted field,

The dying word of a friend weighs over me.

How, oh how can I be comforted? How, oh how will I cry?

My beloved friend is now like dirt,

And will I not lie down like him, so that I will never rise? " (translation

by Gumilyov 1919, p. 50)

Humanity found the answer to Cilgamesh in the religious forms of social consciousness. This answer is simple: live, observing certain moral rules, and you will find the bliss of eternal life after the separation of the immortal soul from the mortal body. The impossibility of empirical control over the correctness of this statement was compensated with the faith, which was actively supported by the professional clan of the clergy.

Differences between different confessions in this case do not matter. They can be compared, according to the patriarch of the Russian Orthodox Church Kirill, with differences in the clothes of persons of different nationalities. The main thing in every confession is faith that our life on the Earth has its meaning as the human being is immortal and the world around us is infinite. But with technological progress this belief that was most seriously shaken especially at the stage of the sixth technological order or NBIC-convergence*.

Man has penetrated deeply into the secrets of being. He clearly realizes that civilization is finite. The astrophysicists calculated that in some four billion years the Solar System as a particle of the Milky Way galaxy will be absorbed by the spiral galaxy Messier 31 (in common words - the Andromeda' Nebula) and will stop its existence. Of course four billion years is a chronological distance, unattainable for an ordinary person with a species life expectancy of 70 years. But the nuclear explosions on Hiroshima and Nagasaki in August 1945 and the test explosion of a hydrogen bomb with a capacity of 58.6 megatons on Novaya Zemlya in October 1961 is the objective reality of the life of generations born after 1945. And these objective realities prove that the end of the world can be man-made and doesn't need either God or Devil for it. And the coronavirus pandemic is further confirmation of this. Although a WHO group of experts studying the causes of the pandemic concluded that the leak in the Wuhan laboratory is "the least likely hypothesis", the causes of the pandemic, as stated by WHO Head T.A. Gebreyesus, require further investigation, possibly with additional missions with participation of special experts" (WH0..., 2021). That is, the possibility of artificial synthesis of viruses is not denied. Including synthesis by felon persons from international terrorist organizations.

The ideological basis of the activities of these organizations is religiosity and pseudoreligiosity. The overwhelming majority of suicide bombers are convinced that by crossing the line between life and death, they open their way to eternal bliss. And this conviction is the second facet of the ideological catastrophe in which humanity finds itself. On the one hand, 
the population in developed countries is losing faith in the sacred ideals of immortality and resurrection, because they see them as being in blatant contradiction with the achievements of scientific and technological progress. On the other hand, these same achievements of scientific and technological progress, falling into the hands of illiterate religious fanatics in poor countries, can easily become instruments for the destruction of life on Earth. Where is the way out of this impasse?

It seems that the most important means of concentrating the efforts of the world community on the direction of solving global problems should be precisely the new political thinking, the worldview of cooperation and universal human unity. A depressing example of M.S. Gorbachev's new political thinking shouldn't discourage us. The fiasco of perestroika ideology is explained by its separation from the broad masses and by its orientation towards political elites who saw in it a means to achieve their selfish goals. The absence of a positive alternative to the prospects for scientific and technological progress also affected.

\section{New church reformation}

The new political thinking of the 21st century should be based on the idea of a deep church reformation. Religion has always formed the basis of ideology, determined the cliches of moral behavior, the criteria for good and evil, guidelines in determining the meaning of life. Church institutions were never given once and for all, they were constantly transformed and adapted to specific socio-economic conditions. As a rule, these transformations were accompanied by dramatic political upheavals - the Church schism in Russia, the Thirty Years' War in Europe, etc. In the transitional periods from one religious formation to another, intermediate, as a rule, short periods of unbelief and atheism arose. At the same time, atheists were not always immoral people. They were also guided by moral canons formulated in religious texts. A kind of bridge of morality between believers and atheists was the concept of conscience (Gewiss) - the sense of moral responsibility before the people around them, society.

The specificity of the current crisis of civilization is that it is not accompanied by the emergence of any new religious forms. Hence the massive spread of itsism- belief in something. The crisis of religion is tightly interrelated with the crisis in natural science. Scientists of our time cannot offer mankind a constructive alternative to self-destruction as a consequence of the increasingly aggravating global challenges and threats.

The current situation is illustrated by the naive idea of the possibility of saving mankind by settling in outer space. Although elementary mathematical calculations and physical studies show that going beyond the solar system, not only billions of people, but even individual astronauts are problematic, nevertheless, the myth of the possibility of moving to other planets similar to Earth is still in circulation. But even if this myth had any rational basis, it remains an immutable truth that after a certain period of time (about 4 billion years) our Galaxy will be absorbed by a star system, known as the Andromeda nebula. Thus, we come to the conclusion that the formation of new political thinking in the modern era should be carried out within the framework of a completely new mega-historical (Big History) approach, operating in chronological segments not in decades, but in hundreds and thousands of years.

This approach was characteristic, in particular, of the French philosopher P. Teilhard de Chardeu. He viewed history as a process of curtailment or interiorization (enrollment), a series 
of transformations, during which the objective reality surrounding a person is increasingly miniaturized. In the 21st century, the theory of the French philosopher found unexpected confirmation in the writings of the British marketer G. Moore, who empirically discovered the law of a constant increase in the amount of information in a decreasing volume of space. Indeed, the amount of information of one smartphone of our time cannot be compared with the scanty amount of the first electronic computers.

The question arises, what are the prospects for this process. According to system engineers and specialists in the field of informatics, the physical limit of the improvement of computer technology will be reached in the so-called point of singularity somewhere in the middle of this century, when the information saturation of the brains of all mankind will fit into one computer. The possibility of abiogenic creation of artificial homo sapiens based on bionic modeling will become a reality by this very time.

This level of scientific and technological progress will raise the original question about the meaning of our existence and the historical purpose of homo sapiens in a new way. Science is not able to provide answers to the questions that arise. In general, according to I. Goethe, science gives an answer only to the question "how?", When a person asks the question "why?", He turns to religion.

Let's turn to religion too.

\section{New technological religion}

The strength of the influence of any confession on the flock depends on how convincingly it substantiates the belief in the reality of such sacred dogmas as immortality, resurrection, heaven, hell, and the last judgment.

At the center of this system of sacred concepts is the figure of a deity, embodying the ideal of man himself, which he should be in everyday reality. The dependence on this human figure in all confessions has always been complete and limitless. The first breakthrough in this system of values was made by Protestants in the era of the formation of national capitalist states, when they clearly pointed to human labor as the basis of being and the meaning of human life. The result was not long in coming, the Protestant workaholics, who moved to the New World, created a powerful state of advanced technologies and technological progress over the course of several decades. But our time requires a new reading of the sacred canons. And this reading does exist. At the historical stage of NBIC-convergence, all religious dogmas can be designated as tasks of applied science:

- immortality - artificial prolongation of specific life span of human beings;

- resurrection - bionic creation of anthropoidentical models of individuals who lived before on the basis of information they left about themselves;

- Last Judgment - selection among those who used to live in line for bionic anthropoidentical modeling;

- paradise - meeting with loved ones and relatives who have passed away earlier.

For a long time, the concept of man-made immortality and resurrection has been overturned by the question of a possible living space for them.

It seems to us that the way to solve this problem is also found by modern science. As one of the leading experts in the development of social networks and communications $M$. 
Zuckerberg testifies, the next stage in the development of inter-human communications will be telepathy or the third signaling system. That is, the thoughts of one person will be read by other people who are in communication with him. M. Zuckerberg presents this eventuality only as the next steps in the development of his network "Facebook". In fact, however this eventuality marks the end of the existence of homo sapiens as a means of matter to realize itself. After all, if we imagine the process of constant overflow of information from one person to another, then the logical end of this process will be the achievement of the complete identity of all participants in the communication process. That is, they can all be united in the process of a great fusion in one being, something similar to a Deity. The enrollment developed by P. Teilhard de Chardin in his "Human Phenomenon" will be completed.

In order to imagine speculatively what will follow this Great Fusion let us address the other phenomena, thus the phenomena of Big Bang. Firs, we should accept the fact that there is still no answer in science to the question of what the Big Bang was. It is only known that at one point in space there was a colossal release of energy, which continues to this day. Thanks to this release, matter, organic matter, plants, animals, intelligent people were formed.

But simultaneously with the expansion, the process of compression (enrollment), concentration of information, up to its centering at one point, began in parallel. What will happen at this point when we cross the line of the singularity? Trying to answer this question properly, do we have the right to anticipate that "our" Big Bang, to which we owe our existence, had been the product of the same concentration of information at the previous stages of the movement of matter and spirit?

In comprehending these processes, science has reached an obvious dead end. Having discovered the last material particle - the Higgs boson, scientists are increasingly beginning to look for answers to questions of natural science in religion. The Higgs boson itself was called firs the particle of Devil and then found its final name as the particle of God. And it is in religion that one should, in our opinion, look for an answer to the question of what should be the foundations of a worldview that should help mankind resist the threat of self-destruction.

Formally, a new technological religion should not differ from the classic traditional one. It should contain the same sacred concepts - immortality, resurrection, eternal life. As we wrote above, all these concepts in the era of NBIC-convergence can be interpreted as tasks of applied science. There is only one concept that needs to be re-interpreted. This concept is God. In classical religion, God is the creator of all the surrounding man and the arbiter of the destinies of man and mankind. The history of religion is the history of the transfer of responsibility for the future of man from God to human being himself. The final stage of this process is technological religion, in which the concepts of God and man merge into a single whole. The human body thus acquires meaning as a kind of vehicle for the journey of God in the universe. The end of this process also seems natural - the collapse of humanity, the concentration of all information in one person of God and his subsequent exit to new spaces through a new Big Bang.

\section{Technological religion and political thinking}

Classical religious confessions divide people. In the past, many wars were religious in nature. In our time, there are many interpretations of the civilizational split as a barrier between the Christian world and the world of Islam. Technological religion is alien to strife 
between people. It unites everyone on the basis of a desire to save humanity and ourselves. But unlike classical religions, it denotes a specific path to achieve these goals.

In modern public consciousness, there is no idea about the goals of cognition. But there is a fear of dehumanization and submission to super intelligent robotic monsters of the future. And these threats, as studies show, have a very real basis, since super intelligent robots that may be created in the future will acquire the ability to self-learn and may get out of the control of their creators. The idea of man as a particle of God gives the process of cognition a real meaning and content. It is necessary to create super intelligent cybernetic robots not so that they tie shoelaces on people's shoes, but in order to create anthropoidentical bionic models of real people who lived in former times. The material for the construction of such models should be the information that we have about these people.

It is believed that information about some people and events of the past has been lost forever. But nevertheless, the more we move forward, the more we learn about the past, the more perfect the means of this knowledge become. And no one can say where the end of this process is. But if we assume that the program for the development of our entire civilization was laid in the Big Bang, then it is also logical to assume that we already existed before this first Big Bang. What we are now is only repeating ourselves at a higher quality level. In other words we get the option to correct mistakes we had committed before Big Bang.

In the recreation of our ancestors, the goal of world development is also seen on the way to the next round in the movement of space-time along a spiral upward. And this goal is very close to the basic receipts of many classical traditional religions and confessions. The idea of ancestor veneration is, for example, an essential part of the Japanese cult Shinto. To some extent or another, it is characteristic of Confucianism, Islam, Buddhism and all Christian denominations. In Orthodoxy the Russian thinker Nikolay Fedorov laid the foundation for the mentality of Russian cosmism. The core of this mentality is the idea of love for fathers. In different historical eras and in different parts of the world, the ideas of man-made immortality and resurrection were shared by Aristotle, Empedocles, Johann Goethe, Antonio Gramsci, James Dana, Mirza Hussein Ali Nuri, Jawaharlal Nehru, Jalaladdin Rumi, Jean-Paul Sartre, Chen Yu, Albert Einstein, Karl Jaspers and many others.

Attempts to establish such a single universal church have been made earlier. In particular, in the nineteenth century an independent confession spun off from Islam Baha'i, which is still functioning today. A distinctive feature of this denomination is its tolerance towards all other confession. The entrance to the Bahai temple is open to adherents of Islam, Christianity, Judaism, Buddhism, etc. The respect for rational scientific knowledge can be found in the fundamental documents of Baha'ism too. But at the time of the birth of Baha'ism, there was still no material basis for the creation of unity of faith.

At about the same time when Bahaism was born in the East, the first communist group was created in the West by Wilhelm Weitling. This group had all features of religious confession including its leading slogan "All Humans are brothers!". Russian Social Democrats A.A. Bogdanov and A.V. Lunacharsky tried to develop a religious character that was originally characteristic of this ideological trend. But the movement was monopolized by politicians and retains its political character to this day. Meanwhile, the outstanding British philosopher A. Toynbee considered communism to be essentially religious worldview, a kind of "chrysalis" from which a new united world ideology could be born in the future (Toynbee, 1948, 13).

An attempt to create such an ideology is currently being undertaken in the United 
States by transhumanists. However, like communism in Russia at the beginning of the 20th century, American transhumanists of the 21st century are strongly influenced by the current political and business environment. As a result, the humanistic and progressive ideas of transhumanism as such remain in the shadow of pseudoscientific cryonics projects.

\section{OSCE and New Political Thinking}

The perception of the OSCE as an "ordinary" international organization, a kind of UN on a regional scale, has taken root in the public consciousness. Sometimes an emphasis on the human rights dimension of the Organization is added to this notion of a "normal" organization. With this perception, the main specificity of the OSCE, its revolutionary character in relation to all other forms of international communication, is fading into the shadows.

Meanwhile, the OSCE played a significant role in transforming the system and structure of international relations at the stage of humanity's withdrawal from the Cold War. With the elimination of the "bipolar" structure of the world order, which had ensured for four decades the state of "armed stability" in Europe and throughout the world, a need arose for a new democratic world order and a new mechanism for maintaining security and stability based on a balance of interests of all subjects of international communication, respect for human rights and fundamental civil freedoms. It is the individual (human being) not the state that should have been placed at the core of the historical process. The international community, represented by the OSCE, received an instrument, the operation of which was based on the classical Hellenistic principle of the primacy of human values over all others on the basis of the well-known formula of Protagoras - "the measure of all things is a man" (Protagoras, 1983: 543).

In the context of the fight against the COVID-19 pandemic, it seems especially important to emphasize this anthropocentric principle of the OSCE, since traditionally it is interpreted only in the context of the Organization's activities in the human rights and electoral directions. Meanwhile, this is not at all about much more - about the adopted by it principled approach to international security and cooperation.

Long before the current pandemic the former OSCE Secretary General Giancarlo Aragona stressed that "from the very beginning of the Helsinki process, the CSCE (now the OSCE) considered security more than a matter of military security. One of the main elements of our security concept is the so-called human dimension. Although there is no definition of the human dimension in any document, it is a much broader concept than human rights (emphasized by the author). In the broadest conceptual framework, it includes all aspects of the human factor in the issues of peace and security" (Aragona, 1997).

The OSCE became the first international organization that fixed the primacy (jus cogens of international law) of a person and his interests over the interests of a state. This primacy and the relevant obligations of the participating States were fixed in the OSCE Charter of Paris (OSCE documents, 1990), and then in Copenhagen (OSCE documents, 1990) and Moscow (OSCE documents, 1991) documents. "The commitments undertaken by states in the field of the OSCE human dimension," says, in particular, the Moscow Document, "are the subject of direct and legitimate concern of all participating States and do not relate exclusively to the internal affairs of the states concerned" (OSCE documents, 1991).

The acceptance of human interests in the activities of the OSCE did not initially 
contradict the interests of states as collective spokesmen for the interests of national interests. Harmony between state interests and democratic freedoms is ensured by the procedural rule of consensus (unanimity) when making decisions. We often hear that the principle of consensus is blocking the OSCE and hindering its effective functioning. In reality, the rule of consensus does not at all prevent the adoption of decisions on the most important issues on the agenda, especially on issues related to new challenges and threats. Such decisions were adopted, inter alia, on the fight against human trafficking (MC.DEC / 2/03), tolerance and non-discrimination (MC.DEC / 4/03), the OSCE counter-terrorism network (MC.DEC / 6/03), reliability documents for entry and exit (MC.DEC / 7/03), on portable anti-aircraft missile systems (MC.DEC / 8/03), stockpiles of conventional ammunition (MC.DEC / 9/03) and other topical issues.

Confronting the pandemic is one of such consensus areas of OSCE activity. Moreover, the founders of the Organization foresaw the growing need for cooperation in this area and created the necessary legal and political instruments for this. So, in particular, even in the section on cooperation in the field of economics, science and technology and the environment of the Helsinki Final Act, in Chapter 4 Science and Technology, the participating States stated that "scientific and technological co-operation constitutes an important contribution to the strengthening of security and cooperation among them, and that assists the effective solution of problems of common interestand the improvement of the conditions of human life"). The Final Act contains also specific provisions stimulating scientific and technical cooperation, including in the field of Medicine and public health, namely "research on cardiovascular, tumor and virus diseases, molecular biology, neuro physiology; development and testing of new drugs; study of contemporary problems of pediatrics, gerontology and the organization and techniques of medical services) (OSCE documents, 1975)). The OSCE Maastricht Document was also called upon to concentrate the world will when discussing issues of a consensus nature in order to make effective decisions of a universal nature, which enshrined the principle of a multidimensional concept of common, comprehensive and indivisible security based on cooperation (OSCE documents, 2003).

The content and spirit of the aforementioned basic documents of the OSCE is consistent with the joint statement of the participating States on COVID-19 of December 15, 2020, which emphasized "the importance of scientific and technical cooperation in response to the spread of the pandemic, in particular in the field of health ..." (We underscore the importance of scientific and technological co-operation in responding to the pandemic, particularly in the health sector ...). The participating States "noted" with satisfaction the significant progress in the development and supply of COVID-19 vaccines, vital for human health and security/note with satisfaction the significant progress on the development and supply of COVID-19 vaccines, vital for human health and security)...( OSCE documents, MC.DEL/78/20)

However, we have to admit that the means and tools mentioned in the Helsinki Final Act are not being fully utilized. In research, licensing of dosage forms and vaccines, their gratuitous distribution and commercialization, there is an open competition that has come to be known as "vaccine war".

To overcome political obstacles in resolving issues of a consensus nature, the OSCE needs two major supporting pillars. The first is ideology. The second is a mass base, something more or less identical with a broad international social movement or even a party. A kind of historical evidence that it is a broad social movement that can overcome political prejudices 
can be the abolition by the Japanese authorities of restrictions on the import of Soviet drugs against child poliomyelitis in the fifties of the XX century.

With regard to ideology, such should be a new political thinking and a new technological religion, the main content of which we have described above. The situation with the party is more complicated. The OSCE is founded on shared values that imply political pluralism in the organization of society while respecting human rights and fundamental civil freedoms. The mention of a strong party, especially a ruling one, is often associated in the public perception with totalitarianism and infringement of democratic freedoms.

The public movement in support of the principles and values of the OSCE is completely opposite in its political content to any dictatorial aspirations. The point is that, on the basis of numerous and, as a rule, scattered public organizations that maintain partnerships with the OSCE in the interests of promoting its fundamental values, form a universal structure with the aim of supporting the implementation of consensus decisions through public actions, as well as on social networks.

Relying on such a structure, the OSCE could strive for the strict implementation of its consensus decisions and claim in the long term the role of a kind of "world government" within the geographical area of its responsibility.

\section{The scientific substantiation of OSCE decisions}

The pandemic has highlighted the need to increase the scientific substantiation of decisions taken by the OSCE and other international organizations on issues related to global challenges and threats. Politicians, as a rule, are wary of the intrusion of scientists into their sphere of activity. And they are right as understanding the scientific content of the historical process scientists cannot always assess and foresee the reactions of the broad masses of the population to certain technological solutions. Characteristic in this respect is the reaction of people to the $5 \mathrm{G}$ telephone communication installation in some regions. Many protesters sincerely believed that the further spread of the $5 \mathrm{C}$ network was invented for the purpose of irradiation and microchipping [ITARNASS, 2 of May, 2020].

Meanwhile, scientists and politicians can establish effective interaction for protecting the interests of those very broad masses of voters who are not always able to understand the technical and medical details of a particular critical situation. At the same time, naturally, politicians should be aware of the full responsibility for the decisions made, relying on scientific expertise. The state of the world community is far from this. The aforementioned OSCE Maastricht Document on Challenges and Threats in the 21st Century, adopted at the Ministerial Council meeting in Maastricht in December 2003 (OSCE documents, Maastricht, 2003), ignores the very existence of a threat to the survival of mankind due to uncontrolled progress in modern technologies development. This threat however was mentioned in a number of authoritative documents of the academic community (See, for example, the forecast project of the Institute of World Economy and International Relations of the Russian Academy of Sciences, carried out seven years before the signing of the Maastricht Document ((Bykov 1995, p. 58). To please the electorate, politicians often keep silent about the existing challenges and threats. but all modern textbooks on global studies underline the special nature of the threats of the 21st century and state that, very existence of mankind is in danger. The prominent Russian expert on global problems ArkadyFedotov wrote in the preface 
to the presented book: "The existing Earth civilization is taking itself into oblivion. Therefore, it must be radically reconstructed" (Fedotov 2002, p. 4).

In the history of the OSCE, there is a positive example of using the world's scientific potential in order to search for options for solving global problems. This example was given by the Organization's Scientific Forum, held from February 18 to March 3, 1980 in Hamburg. The Forum was attended by prominent scientists of our time, who presented reports on four most important areas of world science: alternative energy sources, food production, public health and medicine, humanities and social sciences. Despite the opposition of political puppeteers who sought to politicize the meeting, the scientists managed to conduct a meaningful dialogue or as chief of American delegation Dr. Philippe Handler said "to talk shop". In the focus of this "talk" were the new challenges and threats associated with scientific and technological progress. The scientists managed to develop specific recommendations for the governments of the OSCE participating States. For example, Swedish scientists were seriously worried by nuclear power stations' safety. Upon their insistence the recommendation that "all aspects of the nuclear fuel cycle will require further efforts to ensure its complete reliability and safety so that it is acceptable to the population" was inserted into the text of Forum's final document (OSCE documents, Doc. HUM SOC / GEN 12, Hamburgh,2018).

Unfortunately this recommendation was not taken into account. Six years later, it was Sweden that turned out to be among the first victims of the Chernobyl disaster. Even more informative were the recommendations of medical scientists and virologists, who urged that "existing programs in the field of virology continue and expand" (OSCE documents, Doc. HUM SOC / GEN 12, Hamburg, 2018). Epidemiological crisis 2020 - 2021 can be explained, among other things, by ignoring this recommendation of scientists by politicians, economic and financial leaders of world's countries. The 1980 OSCE Scientific Forum set an important precedent for a joint international brainstorming attack commissioned by the international community. As a result, a recommendation was made that the participating states "study the possibility of convening a new" Scientific Forum "at a suitable time, depending on the development of science and scientific cooperation between the participating states" (OSCE documents, Doc. HUM SOC / GEN 12, Hamburgh,2018).

The COVID-19 pandemic has shown the need for constant scientific monitoring of potential challenges and threats. At the same time it came to light in the course of professional international contacts during pandemic that this permanent monitoring doesn't need expensive face-to-face conferences and symposia. A permanent webinar of scientists from various fields of knowledge and globalists is needed. The composition of the webinar participants and the list of issues to be discussed and monitored should be determined by the governments of the OSCE participating States. In the intervals between face-toface forums convened on a regular basis, contacts between the most prominent scientists would be supported by modern means of communication by a small operational permanent coordination center of the OSCE Scientific Forum, whose tasks would include summarizing and reporting the results of scientific expertise on topical issues to the OSCE participating states.

The pandemic has highlighted the need to improve the efficiency of work with non-governmental organizations, its qualitative transformation using modern means of communication and social networks. The organization should not only exchange information with these organizations and invite them to the annual implementation review conferences, 
but be in daily operational contact with them in order to organize specific public actions in support of the OSCE activities. Practical assistance to the Secretariat in the implementation of these tasks could be provided by a fundamentally new body for public relations - the Center for Non-Governmental Organizations (CNGO).

\section{Lessons learnt}

The global epidemiological crisis that broke out in 2020 is a consequence of a lag between technological progress and its evaluation by politicians and diplomats. "Minerva's owl flies out at night", - so characterized this lag Immanuel Kant. I remember that famous writer of our time Arthur Clark having got the floor of Geneva Disarmament Conference was more categorical: "You are like boys arguing who has more matches while standing tin the pool of gas".

Anticipating eventual new challenges and threats of this kind requires the formation of a global management of the world community. The most important prerequisite for this is the development and dissemination of political thinking (ideology) based on the primacy of universal human values, relying on the common spiritual and moral potential of the main world religions, as well as on such principles and concepts as the pursuit of peace and justice, dignity, freedom, responsibility, honesty, mercy and hard work.

Solving this problem requires a new technological interpretation of such sacred religious concepts as immortality and resurrection. On the basis of such a reading, it will be possible to form the political will necessary for the survival of humanity. One of the most effective instruments for realizing this will can be the Organization for Security and Cooperation in Europe. To this end, the OSCE apparatus should be supplemented with instruments of permanent communication with both scientific organizations and with mass movements of the public.

The source of optimism in solving these problems for us is the fact that the process of realizing the belonging of all people to a single earthly civilization has already begun. To paraphrase Ernest Hemingway, we can say that the alarming bell of global problems awakens the understanding that it is ringing "for everyone". Regardless of national, social, confessional or any other affiliation. But scientific and technological progress, which develops according to its own logic, is catastrophically fast, outstripping the process of its understanding by homo sapiens at the level of the mass consumer. It cannot be ruled out that there have already been cases in the Universe when in this race between reason and technology, technology won. Understanding this eventuality should help the earthly civilization find the strength to organize itself and continue its existence beyond the qualitative border of the technological limit.

\section{References}

1. Democratic Consolidation in Eastern Europe: the Role of the OSCE (1997). Seminar Address by the Secretary General of the Organization for Security and Co-operation in Europe, Amb. Giancarlo Aragona, European University Institute, Florence, 14 October. 
2. Élémensd'idéologie (1817) Première partie. Idéologieproprementdite. Par M. Destütt Comte de Tracy, Pair de France, Membre de I'Institut de France et de la Société Philosophique de Philadelphie. MmeVecourcier, imprimeur-libraire, Paris.

3. Fedotov A.P. (2002), Globalistics: Principles of Science about the Modern World, Course of Lectures, in Russian, Moscow.

4. Gilgamesh, Babylonian epic (1919), translation by N. Gumilyov, Z.I. Grzhebina (ed.), St. Petersburg.

5. Great Encyclopedia of Cyril and Methodius (1998), BRE publication, article "Ideology", electronic version.

6. "Идеологиясверхпотребления - опасность, сравнимая с тоталитаризмом. Каквыжить в условияхисчерпаниявсего?" (2016), Nakanune.RU, online:https://www. nakanune.ru/news/2016/06/17/22439095/.

7. „В Северной Осетиисожгливышку телефоннойсвязииззаопасениявозможноговвода 5G" (2020),ITARTASS, 2 May, onlinehttps://tass.ru/ obschestvo/8388839.

8. IMEMO RAN,International Relations of the Next Decade and Russia (1995).

9. OSCE Documents (1975). Helsinki Final Act, Helsinki.

10. OSCE Documents (1990). Paris.

11. OSCE Documents (2020). MC.DEL/78/20, Chairmanship Statement on COVID 19, 15 December.

12. OSCE Documents (2003). Eleventh Meeting of the Council of Ministers 1 - 2 December OSCE Strategy to Address Threats to Security and Stability in the 21st Century.

13. Action in Europe: The Role of the OSCE, Speech by the Secretary General of the Organization for Security and Co-operation in Europe, Ambassador Ciancarlo Aragona at the International Conference on Preventive Strategy Tokyo, 13 January 1998.

14. Soviet Encyclopedia (1983), "Philosophical Encyclopedic Dictionary", Moscow.

15. Scientific Forum of the Conference on Security and Cooperation in Europe (1980) Hamburg, Doc. HUM SOC / GEN 12.

16. Toynbee A.J. (1948), Civilization on Trial. New York, Oxford University Press.

17. WHO Report on the origin of the coronavirus (2021), Kommersant, March 30, online:https://www.kommersant.ru/doc/4751764.

18. Yakovenko A.V. (2014), "After the death of ideology, Once again about diplomacy in the XXI century", in: Russia in global politics, no. 4, online: http://www.globalaffairs.ru/ number/Posle-smerti-ideologii-16919 